Escritura y Pensamiento 20-24(40-48), 2021, 473-481

\title{
TRES POETAS LATINOAMERICANAS: ANA ELISA RIBEIRO, JOAN LOBATO Y EVA CASTAÑEDA
}

La poesía latinoamericana sigue siendo una ruta aberta; sabe de su apego a lo que vive, siente, percibe; a lo inexorable y súbita realidad y a los continuos desafíos de la fantasía y la imaginación. Del confinamiento y ganas de decir - escribir, ganados por la forma - para ser escuchados en lo que va de la pandemia. Por cierto, a ese apego de hacer que el poema sea exactamente poesía, el Taller de Poesía de San Marcos, el 7 de enero de este año, en plena pandemia, organizó el recital Cuatro Poetas Latinoamericanas; problemas de conectividad impidieron que una de ellas nos acompañara.

Aquí presentamos a las tres poetas que participaron del Recital: Ana Elisa Riberio (Brasil), Joan Lobato (Perú) y Eva Castañeda (México); todas ella con un tono propio y una manera de llegar a sus lectores. Las tres poetas tienen una escritura que los acerca y lo distancia: el desapego, una suerte de ironía y desparpajo que nos aleja de una poética ingenua ubicándonos en la dimensión de una textualidad que no se declara feminista, sino palabra de mujer; de constataciones, de vacíos y desafíos, de nuevos sentidos y formas (poesía-imagen, poesía-violencia, poesía-cuerpo) que ponen en cuestión y resquebraja continuamente lo hegemónico como experiencia novedosa.

Ana Elisa Ribeiro (Belo Horizonte, Brasil, 1975) es profesora da Red Federal de Educación, editora e investigadora, doctora en Lingüística. Su poética está cruzada por la vida cotidiana, 
la memoria, y en sus últimos libros, por la creación de imágenes poéticas desde lo fotográfico o el juego de palabras, que convierten a su poesía en disidente y sublevante. Su concepto de poesía se aproxima al juego y desafío, así "poesia / não atende / pelo nome. / poesia / não pinta / nem pousa ("Poesía"). Ha publicado ocho poemarios; sus últimas publicaciones son Xadrez (2015), Álbum (2018, premio Manaus) y Dicccionario de Imprecisiones (Impressões de Minas, 2019).

Joan Lobato Hoyos (Lima, 1984), linguística y profesora, ha estudiado Escritura Creativa en el Posgrado de Letras de nuestra Universidad. Se trata de una poeta joven que escribe sin prejuicios, que reinventa el erotismo. Lo suyo es una poesía del ritmo y de experimentación de formas. Amazona (en prensa), celebra la "poética del cuerpo, donde yo lírico, bastante marcado, va más allá de las marcas feminista, su eje es el cuerpo", donde yo-mujer es cuerpo, afirmación.

Eva Castañeda Barrera (Ciudad de México, 1981) poeta e Investigadora de UNAM, una de las fundadoras del Seminario de investigación en Poesía Mexicana Contemporánea, fue jefa de redacción del Periódico de Poesía de la UNAM (2012-2015). Se caracteriza por un lenguaje coloquial, que poetiza el habla popular, por momentos de tono vanguardista, sorprenderte y sorpresiva para el lector. Su poesía está marcada por la violencia, eso que forma parte de nuestra historia, se pregunta: “¿Nada sucede en la página? El mundo excede lo imaginable. Escribes para que algo acontezca". ("La poesía”). Ha publicado Nada se pierde (2012), Gramática del memorial (2014), La imaginación herida (2018) y Decir otro lugar (Elefanta, 2020), prosa poética.

Nos corresponde volver a ese "género menos popular", según el decir de Eva Castañeda. Al final, nos queda la poesía. (Gonzalo Espino Relucé) 


\section{ANA ELISA RIBEIRO}

\section{Série de desapreços da pandemia}

1.

Confete e serpentina

Para um carnaval que não passamos

Para um carnaval sem gente

Para depois lavar o cabelo

e tirar papel sujo e amassado

de entre os fios emaranhados

2.

Postas sem os ossos

Postas sem espinhos

Peixes ricos em ômega 3

Peixes que possam ser assados

E o limão da primeira lista

sem poder ir ao mercado

3.

Os itens de um almoço a sós:

apenas o imprescindivel 
4.

Pijamas foram os

itens mais procurados

do e-commerce mundial.

Recuperamos também as

listas de telefones e os canais de tv.

5.

Listas de afazeres

Listas de desfazeres

Listas de desprazeres

E acabamos gostando de não

cumprimentar ninguém.

Nossa lista de quereres

em stand by. 


\section{JOAN LOBATO HOYOS}

\section{CUERPO}

Aún me cobijo en los cuerpos que he amado

Y toco con la punta del deseo

el ayer perdido

Asî

Me dejo llevar

por el cardumen

de muslos delirantes

espaldas en caída libre

y dedos sublimes.

De pronto

Abrazo

Muslos

Espaldas

Dedos

$\mathrm{Y}$ trato de armar

un solo cuerpo

Pero nada encaja.

Entonces

me pongo de pie

$Y$ reconozco

que el único cuerpo

Que me cobija

Es el mío. 


\section{MAGNITUDES}

El peso y la masa

La masa y el peso

Nada es igual

Con la gravedad tirándote de las arrugas

Mi espalda cede

cada noche

ante el deseo

Y hay una masa palpitante

que se extiende más allá de mi cama

¿Qué haré, qué haré, señor, con las sobras de este cuerpo?

El tiempo no borra la agonía de la soledad de un cuerpo. 


\section{EVA CASTAÑEDA}

\section{Tu teoria sobre la desaparición del mundo y nuestro empeño por inventar historias. Cuéntame:}

Que todo se termine sin nostalgia ni piedad.

Punto.

Primero será el silencio como una tregua.

Entonces le diremos al mundo que sí pudimos, que todo se nos rindió

mientras caminábamos en dirección contraria a las bombas que no eran bombas, a la guerra que no era guerra, que tuvimos las claves para interpretarlo todo: ciudades de sangre y rostros borrándose en el tiempo.

Que fuimos valientes porque trazamos las calles para andar por este pais

$\mathrm{y}$ aunque nos vieron no pudieron tocarnos, y aunque nos oyeron su furia se quedó en el aire.

El fin del mundo, te lo juro, no será una explosión.

Será algo más parecido a la marcha de miles de insectos juntos. Será.

No reclamaremos nada, porque yo ahora mismo te estoy diciendo que aquí nosotras, que ahí tú y yo, que aquí él y ella, que aquí te estoy contando cómo terminará aquello que ocupó extensiones, que fue muy grande.

Dijiste sin nostalgia ni piedad que todo se termine: nada ni nadie, no habrá nada, pero antes, más antes, me contarás la última historia. 


\section{Tu teoria sobre la irrealidad del presente. Cuéntame:}

Después de tantas revueltas y guerras del siglo, un repaso por la violencia, tú contándome la historia de la revolución y que el imperio más poderoso será el que más brille: tú diciéndome come fresas con chocolate que aquí están. Ya viste que las cortinas están abiertas y afuera es lo que es.

Piensa: geográficamente nos ha tocado vivir en un sitio cuya ebullición no para, todo el tiempo algo detonan.

Por eso mejor pon tu dedo en esta línea y después mírame bien. Tu mano en el mapa. Tu boca revelando a mi cuerpo como el lugar. Llegamos.

Sé compasiva como la justicia que no llega por más que se busca. Restablece lo que la memoria no debe olvidar: sus gritos, la desaparición, el saqueo, las mentiras. Este país.

Aquí estamos: yo la más fuerte, tú la más hermosa.

Podemos ser él, eso no importa. Aquí estamos en pleno siglo XXI. Explícame cómo se hace. 
Tu teoria sobre la verdad en medio de un país en guerra. Cuéntame:

No somos una multitud homogénea, miranos, óyenos hablar de la gente que todavía calienta sus manos en el fuego. Regresa a ti misma y dime qué ves:

para empezar, la lengua, un territorio que traspasa lindes, por eso nuestro lenguaje híbrido, por eso digo que tu cuerpo es el lugar, su propia evidencia.

Cada una, cada quien traducirá la visión restaurada del mundo, porque algo se puede rehacer.

Así como se pegan los jirones, como se rearma lo despedazado.

Acuérdate: te creo todo.

Es posible juntar.

Probable remendar.

Te hablo de la verdad, y sí lo sabes. 